\title{
Research
}

\section{Analysis of the correlation between post intubation laryngeal injury with the risk factors}

\author{
Lisa Apri Yanti*, Indriati Purwasari, *Abla Ghanie*, Erial Bahar** \\ * Department of Otorhinolaryngology - Head and Neck Surgery \\ **Department of Anatomical Pathology \\ Faculty of Medicine, Sriwijaya University/Dr.Mohammad Hoesin Hospital, \\ Palembang
}

\begin{abstract}
Background: Post intubation laryngeal injury varies in each individual. The occurrence could not be predicted, but it might be related to age, gender, smoking, comorbidities, duration of intubation, reintubation, the type and size of endotracheal tube, the volume and duration of cuff inflation. Knowing the risk factors could prevent and decrease the occurrence of post intubation laryngeal injury. Objective: To find out the risk factors associated with the incidence of laryngeal injury after intubation. Method: This study was a cross sectional design. The samples were taken from medical records of Intensive Care Unit/ High Care Unit patients at Dr.Mohammad Hoesin Hospital Palembang, from January to December 2019. Result: There were 59 ICU/HCU patients suffered post intubation laryngeal injuries. The injuries were varied, with laryngeal edema being the most common injury (89.8\%), followed by widened posterior gap $(52.5 \%)$, and subglottic ulcer $(32.2 \%)$. Based on the Classification of Acute Laryngeal Injury (CALI), the most common post intubation laryngeal injury was severe injury (42.4\%). Multivariate analysis found that intubation more than 7 days had 4.7 times probability of experiencing severe laryngeal injury. Discussion: In our study, there was no significant correlation between post intubation laryngeal injury with gender, comorbidities, smoking, diameter of ETT, and re-intubation. There was a significant correlation between post intubation laryngeal injury, with age, duration of intubation, and kinking type of ETT. Conclusion: There was a significant relationship between severe post intubation laryngeal injury and duration of intubation.
\end{abstract}

Keywords: laryngeal injury, post intubation, risk factors, CALI

\section{ABSTRAK}

Latar belakang: Cedera laring pasca intubasi endotrakeal bervariasi antara satu individu dengan individu lain. Penyebabnya belum diketahui pasti, tetapi mungkin berhubungan dengan usia, jenis kelamin, riwayat merokok, komorbid, lama intubasi, riwayat intubasi berulang, ukuran dan jenis pipa endotrakeal, volume cuff dan lama cuff dikembangkan. Diketahuinya faktor risiko dapat mencegah dan mengurangi angka kejadian cedera laring pasca intubasi. Tujuan: Mengetahui faktor risiko yang berhubungan dengan kejadian cedera laring pasca intubasi. Metode: Penelitian observasional menggunakan rancangan potong lintang (cross sectional). Dilakukan melalui data rekam medik pasien Intensive Care Unit/High Care Unit RS Dr. Mohammad Hoesin Palembang periode Januari-Desember 2019. Hasil: Didapati 59 pasien ICU/HCU yang mengalami cedera laring pasca intubasi. Cedera yang terjadi bervariasi, edema laring adalah cedera yang paling banyak terjadi $(89,8 \%)$, diikuti posterior gap yang melebar (52,5\%) dan ulkus subglotis (32,2\%). Berdasarkan Classification of Acute Laryngeal Injury (CALI), derajat cedera laring pasca intubasi terbanyak adalah cedera derajat berat sebanyak 25 pasien (42,4\%). Hasil analisis multivariat menunjukkan bahwa lama intubasi $>7$ hari berpeluang 4,7 kali mengalami cedera laring derajat berat. Diskusi: Pada penelitian ini tidak didapati hubungan yang bermakna antara kerusakan laring pasca intubasi dengan jenis kelamin, penyakit penyerta, merokok, diameter pipa endotrakeal dan intubasi berulang. Didapati adanya hubungan yang bermakna antara 
kerusakan laring pasca intubasi dengan umur, lamanya intubasi dan pipa endotrakeal tipe kinking. Kesimpulan: Terdapat hubungan yang bermakna antara cedera laring pasca intubasi derajat berat dengan lamanya intubasi.

Kata kunci: cedera laring, pasca intubasi, faktor risiko, CALI

Correspondence address: Dr. Lisa Apri Yanti. Department of Otorhinolaryngology - Head and Neck Surgery, Faculty of Medicine, Sriwijaya University/Dr.Mohammad Hoesin Hospital, Palembang. Email: lisa.abda@yahoo.com.

\section{INTRODUCTION}

Laryngeal injury could be caused by endotracheal intubation. The direct contact of endotracheal tube with laryngeal mucosa during intubation and extubation or the continuous pressure of the tube during anesthesia, could damage vocal cord mucosa. Post intubation throat pain is a common complaint that is caused by focal ischemia, damage to the laryngeal mucosa or edema. However, if the laryngeal symptoms persist after 72 hours, vocal cord paralysis, the formulation of granulation tissue, or ulcers could occur. ${ }^{1}$

The incidence of post intubation laryngeal injury in adult was reported between $4 \%-13 \%$. Around $63 \%$ of acute post intubation laryngeal injury is reversible in 30 days, the rest could become chronic injuries. Post intubation laryngeal injury varies in each individual. Patients with prolonged intubation in Intensive Care Unit (ICU) had the possibility to get severe laryngeal injury. ${ }^{2}$ However, some patients developed severe laryngeal injuries even when intubation period was short. Laryngeal mucosa could be damaged by various factors. The endotracheal intubation process is one of the main responsible factors for lesions. The variation of intubation related injury in airway mucosa is unknown, it may be related to age, gender, smoking, comorbidities such as diabetes mellitus, laryngopharyngeal reflux (LPR), upper respiratory tract infection, duration of intubation, re-intubation, the size and type of endotracheal tube, the cuff size and the duration of cuff inflation. ${ }^{3}$

Globally, there are 13 to 20 million intubated patients in the ICU per year. Laryngeal trauma from prolonged endotracheal intubation occurs in patients of all ages. Most changes are superficial and heal quickly. Injuries that are found consistently during intubation include nonspecific changes, edema, granulation tissue, ulceration, and other miscellaneous injuries. ${ }^{4}$

Lundy et al. ${ }^{5}$ compared the post intubation laryngeal injury between postoperative patients and ICU patients. From his study it was revealed that vocal cord immobility and glottic edema were found in postoperative patients, while subglottic edema and granuloma were found in ICU patients. Although potentially these findings could become a serious injury, larynx evaluation in post intubated patients were not routinely performed, or often delayed executed. The evaluation was performed only if there were remaining symptoms for more than one week, sometimes the evaluation even waited until 1-3 months afterwards. Laryngeal injury from intubation is common in the ICU setting. Guidelines for laryngeal assessment and post extubation surveillance do not exist. ${ }^{6}$

The delayed evaluation was due to the absence of standard practice for post intubation assessment. Therefore, patients with laryngeal injury have increased risk of structural defect such as post intubation 
glottic stenosis, and also functional defects such as dysphonia and chronic dysphagia.

The purpose of this sudy was to find out the risk factors associated with the incidence of laryngeal injury after intubation.

\section{METHOD}

This was an observational study using cross sectional method. The objective was to find out the risk factors associated with the incidence of post intubation laryngeal injury. The subjects were ICU/High Care Unit (HCU) patients of Dr.Mohammad Hoesin Hospital Palembang, through their medical records starting from January until December 2019.

Samples were obtained by total sampling, taking all data complying with the study's inclusion criteria, which were complete medical record of Laryngopharyngology Division ORL HNS Department patients, which had underwent direct laryngoscopy for laryngeal evaluation and underwent tracheostomy in the ICU/HCU. The exclusion criteria were incomplete patient's medical record.
Data was analyzed using Chi-square test to find out the correlation between independent and dependent variables. The logistic regression analysis was used to see the correlation strength between independent and dependent variables. The result of data analysis was presented in tables with narration.

\section{RESULT}

From the medical record since January to December 2019 could be obtained 59 data complied with the study's criteria. Based on age, the highest number was age group 6170 years, as many as 13 patients $(22 \%)$ with mean age $51.3 \pm 19$ years old. The youngest patient was 16 years, while the oldest was 95 years. In this study, female $(54.2 \%)$ was more than male $(48.2 \%)$. The subjects were dominantly non-smoking $(74.6 \%)$, subjects with comorbid was $42(71.2 \%)$, with the highest comorbid was hypertension as many as 24 patients $(40.7 \%)$. The characteristic of risk factors before intubation was presented in Table 1 .

Table 1. Characteristic of risk factors before intubation

\begin{tabular}{|c|c|c|c|}
\hline Variable & $\mathbf{N}$ & $\%$ & \pm SD \\
\hline Age & & & $51.3 \pm 19$ \\
\hline - $<20$ years & 4 & 6.8 & \\
\hline - 21-30 years & 6 & 10.2 & \\
\hline - $31-40$ years & 8 & 13.6 & \\
\hline - $\quad 41-50$ years & 8 & 13.6 & \\
\hline - 51-60 years & 11 & 18.6 & \\
\hline - $\quad 61-70$ years & 13 & 22.0 & \\
\hline - $\quad>70$ years & 9 & 15.3 & \\
\hline \multicolumn{4}{|l|}{ Gender } \\
\hline - Male & 27 & 45.8 & \\
\hline - $\quad$ Female & 32 & 54.2 & \\
\hline \multicolumn{4}{|l|}{ Smoking history } \\
\hline - Yes & 15 & 25.4 & \\
\hline - $\quad$ No & 44 & 74.6 & \\
\hline \multicolumn{4}{|l|}{ Comorbid } \\
\hline - None & 17 & 28.8 & \\
\hline - $\quad$ Present & 42 & 71.2 & \\
\hline \multicolumn{4}{|l|}{ Typed of cormobid } \\
\hline - Diabetes mellitus & 6 & 10.2 & \\
\hline - Upper respiratory tract infection & 7 & 11.9 & \\
\hline - Hypertension & 24 & 40.7 & \\
\hline - More than one comorbid & 4 & 6.8 & \\
\hline - Others & 1 & 1.7 & \\
\hline
\end{tabular}


Based on the characteristic of risk factors after intubation (Table 2), patients with duration of intubation $>7$ days were almost the same number $(50.8 \%)$ with $\leq 7$ days intubation $(49.2 \%)$. The average duration of intubation $8.37 \pm 3.7$ days, the shortest duration was 3 days and the longest was 19 days. Patients with kinking type endotracheal tube (ETT) (49.2\%) was almost the same number with non-kinking $(50.8 \%)$. All patients were intubated with cuff pressure $\leq$ $25 \mathrm{~cm} \mathrm{H} 2 \mathrm{O}$, and the cuff was inflated more than 6 hours. Only 2 patients had a history of re-intubation.

Table 2. Characteristic of risk factors after intubation

\begin{tabular}{|c|c|c|c|}
\hline Variable & $\mathrm{N}$ & $\%$ & $\pm \mathbf{S D}$ \\
\hline $\begin{array}{l}\text { Duration of intubation } \\
\bullet \quad \leq 7 \text { days } \\
\bullet \quad>7 \text { days } \\
\text { Type of ETT }\end{array}$ & $\begin{array}{l}29 \\
30\end{array}$ & $\begin{array}{l}49.2 \\
50.8\end{array}$ & $8.37 \pm 3.7$ \\
\hline $\begin{array}{l}\text { - Kinking } \\
\text { - Non-kinking }\end{array}$ & $\begin{array}{l}29 \\
30\end{array}$ & $\begin{array}{l}49.2 \\
50.8\end{array}$ & \\
\hline $\begin{array}{rr}\text { Size of ETT } \\
\bullet \quad \leq 7.5 \\
\bullet \quad>7.5\end{array}$ & $\begin{array}{l}46 \\
13\end{array}$ & $\begin{array}{l}76.0 \\
22.0\end{array}$ & \\
\hline $\begin{aligned} \text { Cuff pressure } \\
\bullet \quad \leq 25 \mathrm{~cm} \mathrm{H}_{2} \mathrm{O} \\
\bullet \quad>25 \mathrm{~cm} \mathrm{H}^{2} \mathrm{O}\end{aligned}$ & $\begin{array}{c}59 \\
0\end{array}$ & $\begin{array}{c}100 \\
0\end{array}$ & \\
\hline $\begin{array}{c}\text { Duration of cuff inflation } \\
\cdot \quad \leq 6 \text { hours } \\
\bullet \quad>6 \text { hours }\end{array}$ & $\begin{array}{c}0 \\
59\end{array}$ & $\begin{array}{c}0 \\
100\end{array}$ & \\
\hline $\begin{array}{c}\text { History of re-intubation } \\
\qquad \text { Yes } \\
-\quad \text { No }\end{array}$ & $\begin{array}{c}2 \\
57\end{array}$ & $\begin{array}{c}3.4 \\
96.6\end{array}$ & \\
\hline
\end{tabular}

All patients experienced laryngeal injury. The highest injury type of post intubation was laryngeal edema (89.8\%), and arytenoid was the most often affected as many as 52 patients. The second highest injury was widened posterior gap (52.5\%) followed by subglottic ulcer (32.2\%). Laryngeal injury was grouped according to Classification of Acute Laryngeal Injury (CALI). ${ }^{7}$ The highest number of post intubation laryngeal injury was severe injury in 25 patients $(42.4 \%)$. The characteristic of post intubation laryngeal injury was presented in Table 3.

Table 3. Characteristics of post intubation laryngeal injury

\begin{tabular}{lcc}
\hline \multicolumn{1}{c}{ Variable } & N & $\mathbf{\%}$ \\
\hline Incidence of post intubation & & \\
laryngeal injury & 59 & 100 \\
$\bullet \quad$ Yes & 0 & 0 \\
- No & 53 & 89.8 \\
\hline Laryngeal injury & 20 & 33.9 \\
Larynx edema: & 50 & 84.7 \\
Epiglottic edema & 32 & 54.2 \\
Arytenoid edema & 29 & 49.2 \\
Plica ventricularis edema & 10 & 16.9 \\
Plica vocalis edema & & \\
\hline
\end{tabular}


- Laceration

3

5.1

- Granulation

10.2

- Granuloma

5.1

- Intra-arytenoid adhesion

5.1

- Ventricular obliteration

1.7

- Vocal fold adhesion

1.7

- Reinke's edema

- Widened posterior gap

- $\quad$ Right vocal fold palsy

- Left vocal fold palsy

- Bilateral vocal folds palsy

- Glottic stenosis

- Subglottic stenosis

- Supraglottic ulcer

- Glottic ulcer 0

$\begin{array}{cc}0 & 0 \\ 10 & 16.9\end{array}$

$0 \quad 0$

- Subglottic ulcer

- $\quad$ Mild

16

27.1

- Moderate

- Severe

Table 4. Bivariate analysis of risk factors and laryngeal injury incidence based on CALI

\begin{tabular}{|c|c|c|c|c|c|}
\hline \multirow{2}{*}{ Variable } & \multirow{2}{*}{ Category } & \multicolumn{3}{|c|}{ CALI classification } & \multirow{2}{*}{ P value } \\
\hline & & Mild & Moderate & Severe & \\
\hline \multirow{7}{*}{ Age } & $<20$ years & 0 & 0 & 4 & \multirow{7}{*}{$0.020^{*}$} \\
\hline & $21-30$ years & 0 & 3 & 3 & \\
\hline & $31-40$ years & 1 & 3 & 4 & \\
\hline & 41-50 years & 4 & 2 & 2 & \\
\hline & 51-60 years & 3 & 3 & 5 & \\
\hline & years & 4 & 5 & 4 & \\
\hline & $>70$ years & 4 & 2 & 3 & \\
\hline \multirow[b]{2}{*}{ Gender } & Male & 4 & 10 & 13 & \multirow{2}{*}{0.145} \\
\hline & Female & 12 & 8 & 12 & \\
\hline \multirow{2}{*}{ Smoking history } & Yes & 2 & 5 & 8 & \multirow[b]{2}{*}{0.328} \\
\hline & No & 14 & 13 & 17 & \\
\hline \multirow{2}{*}{$\begin{array}{l}\text { Comorbid } \\
\text { history }\end{array}$} & Yes & 12 & 12 & 18 & \multirow[b]{2}{*}{0.861} \\
\hline & No & 4 & 6 & 17 & \\
\hline \multirow{2}{*}{$\begin{array}{c}\text { Duration of } \\
\text { intubation }\end{array}$} & $>7$ days & 6 & 6 & 18 & \multirow{2}{*}{$0.020^{*}$} \\
\hline & $\leq 7$ days & 10 & 12 & 7 & \\
\hline \multirow{2}{*}{ ETT type } & Kinking & 10 & 4 & 15 & \multirow[b]{2}{*}{$0.023^{*}$} \\
\hline & Non-kinking & 6 & 14 & 10 & \\
\hline \multirow{2}{*}{ Tube diameter } & $>7.5$ & 3 & 3 & 7 & \multirow[b]{2}{*}{0.633} \\
\hline & $\leq 7.5$ & 13 & 15 & 18 & \\
\hline \multirow{2}{*}{$\begin{array}{c}\text { Re-intubation } \\
\text { history }\end{array}$} & Yes & 0 & 0 & 2 & \multirow{2}{*}{0.171} \\
\hline & No & 16 & 18 & 23 & \\
\hline
\end{tabular}

Bivariate analysis test showed only age, duration of intubation, and re-intubation history conformed the requisites for multivariate analysis, $p$ value $<0.20$. Other variables were eliminated. The result of bivariate analysis was exhibited in Table 5 . 
Table 5. Bivariate analysis of risk factors and laryngeal injury incidence based on CALI

\begin{tabular}{|c|c|c|c|c|}
\hline \multirow[b]{2}{*}{ Variable } & \multirow[b]{2}{*}{ Category } & \multicolumn{2}{|c|}{ CALI } & \multirow[b]{2}{*}{ P value ${ }^{*}$} \\
\hline & & Non-severe & Severe & \\
\hline \multirow[b]{2}{*}{ Age } & $<60$ years & 17 & 18 & \multirow[b]{2}{*}{$0.152^{*}$} \\
\hline & $\geq 60$ years & 17 & 7 & \\
\hline \multirow{2}{*}{ Gender } & Male & 14 & 13 & \multirow[b]{2}{*}{0.575} \\
\hline & Female & 20 & 12 & \\
\hline \multirow{2}{*}{ Smoking history } & Yes & 7 & 8 & \multirow[b]{2}{*}{0.489} \\
\hline & No & 27 & 17 & \\
\hline \multirow{2}{*}{ Comorbid history } & Yes & 24 & 18 & \multirow{2}{*}{1.000} \\
\hline & No & 10 & 7 & \\
\hline \multirow{2}{*}{ Duration of intubation } & $>7$ days & 22 & 7 & \multirow{2}{*}{$0.012^{*}$} \\
\hline & $\leq 7$ days & 12 & 18 & \\
\hline \multirow{2}{*}{ ETT type } & Kinking & 14 & 15 & \multirow[b]{2}{*}{0.244} \\
\hline & Non-kinking & 10 & 10 & \\
\hline \multirow{2}{*}{ Tube diameter } & $>7.5$ & 6 & 7 & \multirow[b]{2}{*}{0.529} \\
\hline & $\leq 7.5$ & 28 & 18 & \\
\hline \multirow{2}{*}{ Re-intubation history } & Yes & 0 & 2 & \multirow{2}{*}{$0.175^{*}$} \\
\hline & No & 34 & 23 & \\
\hline
\end{tabular}

The result of multivariate analysis revealed that only duration of intubation was affecting laryngeal injury in severe degree. Therefore, should the duration of intubation $>7$ days, the probability of severe laryngeal injury was $60 \%$. In other words, should the duration of intubation $>7$ days, patient had 4.7 times potentiality of severe laryngeal injury according to CALI.

\section{DISCUSSION}

Based on age, the highest number of study subject was age group 61-70 years $(22 \%)$ with mean age $51.3 \pm 19$ years old. Post intubation laryngeal injury incidence in adult was reported between 4\%-13\%. In this study, patients above 30 years of age were within all CALI categorization. The age group who suffered the highest severe injury was age group 51-60 years. There was a significant correlation between age and post intubation laryngeal injury of CALI categorization. Along with the aging process of the larynx, the mucosa layer became atrophic and the elastic fibers reduced. This condition had made the larynx became fragile and more susceptible to trauma. Histologic findings showed decreasing ability of fibroblast in producing extra cellular matrix (ECM), therefore should trauma occurred the wound healing process would be slower, and could be imperfect. ${ }^{3,4,8}$

In this study, female (54.2\%) who suffered post intubation laryngeal injury was more than male (45.8\%). No significant correlation between gender and post intubation laryngeal injury of CALI categorization. Anatomical structure of the larynx in female is different with male, particularly the thyroid cartilage and the vocal cord structures. Male thyroid angle is $90^{\circ}$ while female $120^{\circ}$. The vocal cord of men is longer than women's $(30 \mathrm{~mm}$ vs. $20 \mathrm{~mm}$ ). The difference of anatomical structure between men and women was assumed to be the risk factor for the cause of post intubation laryngeal injury. Oleszewski, ${ }^{9}$ in his research reported that 27 ICU intubated patients consisted of 16 males and 11 females, and amongst them there were 7 males and 3 females suffered post intubation laryngeal injury. Patients with granuloma were 3 males and 6 females, ulceration was endured by 13 males and 10 females, while erythema was 
found in 3 males and 1 female. In his study, no significant correlation was found between post intubation laryngeal injury and gender.

There was no significant correlation between smoking and post intubation laryngeal injury complying with CALI categorization. Our study did not conform the theory that smoking history affected laryngeal condition. The heat coming from smoking had caused oropharyngeal and laryngeal mucosa became dry and sensitive to irritation, in particular it could induce inflammation. Besides the heat, smoking elicits changes of laryngeal mucosa, from mild change as edema to epithelial cell metaplasia. These changes could affect the incidence rate of post intubation laryngeal injury. In edematous condition, the risk of laryngeal trauma increased. ${ }^{3,4,9}$ The result of our study which was contrary to this theory, probably was due to majority subjects in our study were not smoking (74.6\%).

The group with comorbidities had the highest frequency in any CALI categorization. There was no significant correlation between comorbidities and post intubation laryngeal injury (Table 1).

Comorbid such as diabetes mellitus, upper respiratory tract infection, and LPR could hamper post intubation healing process. Gastroesophageal reflux made gastric acid going up and aspirated into the larynx and subglottis. This condition would worsen the local injury, and could become a predisposition for infection, ulceration and granulation tissue forming. An acute or chronic condition with declining consciousness, low tissue perfusion, and hypoxia were related to more severe condition such as anemia, hypotension, hypoxia, heart disease, kidney failure, or hepatic failure. ${ }^{10}$

Infection was also a contributing factor which could rapidly spread in tracheostomy wound, especially in patients with declining immunity or in a bad condition. When tracheostomy was executed below the injured larynx, microorganism contamination through the stoma could hinder laryngeal healing and could increase scar forming of the vocal cord. To minimize infection, all necessary prevention should be carefully implemented. Laryngeal infection was caused primarily by viruses and bacteria, and had important implication in swallowing, phonation and breathing. ${ }^{11}$

Other comorbid was diabetes mellitus. The hyperglycemia condition could delay wound healing process due to vasoconstriction which impeded the oxygen and nutrition for wound healing. Diabetes mellitus also decreased body immunity, thus the infection risk was increased. ${ }^{3,4}$ It was observed that the risk and the incidence of vocal folds palsy had increased with the age and was three times higher in patients of 50-69 years. The risk also duplicated in patients who had diabetes mellitus and arterial hypertension as comorbidities. The fact of diabetes mellitus to be associated with peripheral neuropathy could increase the susceptibility to the vocal fold palsy. Therefore, the recurrent nerve and it peripheral ramifications, and laryngeal muscles and soft tissues could be more vulnerable to the mechanical damages, and to the pressure of the ETT cuff in patients with diabetes mellitus and hypertension. ${ }^{12}$

Beside all the above mentioned, the most frequent comorbid was hypertension (Table 1), and the correlation between hypertension and post intubation laryngeal injury had not been studied. Theoretically, it was hypotension that inhibited the healing process. $^{6}$

Patients with duration of intubation $>7$ days were almost the same number (50.8\%) with $\leq 7$ days intubation (49.2\%). Shah et al. ${ }^{13}$ found in animal experiment that laryngeal injury occurred 24 hours after intubation at a region similar to larynx in human body.

Bishop, ${ }^{14}$ showed ulceration in vocal folds and arytenoid cartilage 48 hours post 
intubation, and also ischemic necrosis in all human larynx 96 hours post intubation or more. Rangachari et al. ${ }^{15}$ stated that the incidence of laryngeal injuries following intubation was between $63 \%$ to $94 \%$, and permanent sequelae were between 10 to $22 \%$ in the world literatures.

Colice et al. ${ }^{16}$ found out $94 \%$ of patients that had been intubated for $\geq 4$ days, suffered laryngeal injury in the form of edema. A typical pattern of laryngeal damage was seen consisted of mucosal ulcerations, along the posterior-medial aspects of both vocal cords and varying laryngeal edema in 77 patients. Santos et al. ${ }^{17}$ stated that the presence of endotracheal tubes had been shown in numerous studies to cause degrees of laryngeal injury. His study reported that the majority of 97 patients who had been intubated for $\geq 3$ days, with mean average 9 days, suffered several types of laryngeal injury.

The group with duration of intubation $>7$ days, had the highest probability of severe laryngeal injury (60\%). There was a significant correlation between the duration of intubation and post intubation laryngeal injury according to CALI categorization. In majority of adult patients, the intubation duration of 5 to 7 days were considered natural and proper, before any further decision to prolong the intubation or to do tracheostomy. The decision to do further action was taken based on patient's general condition and whether extubation could be performed with endoscopic evaluation. The result of endoscopic examination could help to determine the degree of injury and could further lead to the necessary intervention. Laryngeal sequelae after extubation is directly associated with the duration of intubation. ${ }^{6}$

In our study the number of patients with kinking ETT (49.2\%) was almost the same number with non-kinking ETT (50.8\%) (Table 2). The kinking ETT had the highest number of severe degree post intubation laryngeal injury (25.4\%). There was a significant correlation between ETT type and post intubation laryngeal injury of CALI category. This study had an inverse result with the theory that non-kinking ETT could give more laryngeal injury due to its inflexibility, while the kinking ETT was considered more pliable, and assumed to give less laryngeal injury. Benjamin, ${ }^{4}$ stated that ETT with thin metal spiral could lessen the pressure of the ETT silicone layer. It was advisable to use the non-kinking silicone wired ETT to reduce irritation, unfortunately the production price is very costly. In the meantime, the injury caused by ETT pressure could be minimized by using high volume cuff with low pressure.

In our study, the group with ETT diameter $\leq 7.5 \mathrm{~mm}$ had the highest frequency in all CALI categorization. There was no significant correlation between tube diameter and post intubation laryngeal injury of CALI categorization. This could be due to the right choice of ETT size suitable to each patient. A pilot study by Cordeiro et al. ${ }^{3}$ in Brazil 2014, concluded that the following factors associated with post intubation laryngeal mucosal injury were cuff pressure above 25 $\mathrm{cm} \mathrm{H} 2 \mathrm{O}$, intubation duration longer than 120 minutes, and the diameter of tubes larger than $7.5 \mathrm{~mm}$. If the ETT diameter was too big, it caused higher pressure at structures around the posterior larynx. The choice of ETT diameter was commonly based on patient's gender, the average tube size for male was 8.0 $\mathrm{mm}$ and for female $7.0 \mathrm{~mm}$. However, in each case the ETT diameter must be accustomed to each individual size. ${ }^{3,4,8}$

In our study, only 2 patients had a history of re-intubation, and both suffered severe degree of laryngeal injury. There was no significant correlation between history of re-intubation and post intubation laryngeal injury of CALI categorization. There was no research on the correlation between history of re-intubation and post intubation laryngeal injury. However, it was assumed that the 
laryngeal injury could be potentially more severe in patient with history of re-intubation, due to repeated trauma in the laryngeal area.

The cuff is inflated to seal the airway to deliver mechanical ventilation. A cuff pressure between 20 and $30 \mathrm{~cm} \mathrm{Hg}$ is recommended to provide an adequate seal and reduce the risk of complications. ${ }^{18}$

In this study, the correlation between cuff pressure and post intubation laryngeal injury could not be analyzed because all patients were intubated with cuff pressure $\leq 25 \mathrm{~cm}$ $\mathrm{H} 2 \mathrm{O}$. This is because in the ICU/HCU the cuff pressure was carefully monitored by manometry measurement every 24 hours. Should there be over limit or under limit, it would be quickly adjusted. The correlation between the duration of cuff inflation and post intubation laryngeal injury was also could not be analyzed because all cuffs were inflated during installation of ETT, and deflated when the ETT was extubated. Thus, the duration of inflated cuff was the same with duration of intubation, which was 6 hours or more. Theoretically, the longer duration of cuff inflation, the longer the pressure upon laryngeal mucosa, which could accelerate injury occurrence and hampering healing process.

From 59 subjects complying with the study inclusion criteria, all suffered laryngeal injuries. The highest frequency of post intubation laryngeal injury was laryngeal edema $(89.8 \%)$, where arytenoid being the most often affected, as many as 50 subjects. The second and third injuries were widened posterior gap $(52.5 \%)$ and subglottic ulcer $(32.2 \%)$. The injury was probably associated with location, as during intubation the ETT was going down in the direction of posterior of the larynx. Arytenoid is also located in the posterior. Widened posterior gap was probably due to ETT position which stayed in posterior commissure, while subglottic ulcer was probably caused by cuff pressure on the subglottic area. Based on previous studies, the most common area which suffered post intubation laryngeal injury was at posterior glottic region. ${ }^{3-5}$

A prospective research by House et $\mathrm{al},{ }^{2}$ in Boston during 2008-2009 obtained the incidence of post prolonged intubation laryngeal injury were erythema (82\%), laryngeal edema $(70 \%)$, widened posterior glottic gap (95\%), ulceration (31\%), granulation tissue $(27 \%)$, vocal cord immobility (21\%), posterior glottic stenosis (13\%), subglottic edema and arytenoid dislocation less than 5\% each.

Lundy et al. ${ }^{5}$ reported from 45 intubated patients, after evaluation 19 subjects had vocal cord immobility, 12 subjects developed subglottic stenosis, 11 subjects got granuloma, and 3 subjects had glottic stenosis.

Li et al. ${ }^{19}$ found out the pathogenesis of vocal fold scarring is complex. A new understanding of laryngeal wound healing need to be emphasized in further studies.

Kahveci et al. ${ }^{20}$ stated that secondary changes in laryngeal mucosa due to endotracheal intubation were inevitable. To prevent any irreversible sequelae of intubation, it was important to diagnose these changes the soonest. The incidence of laryngeal mucosal injury due to intubation was very high (64\%). The most frequent pathologic finding was ulceration. Endoscopic examination is the best mean to diagnose these lesions.

Histologic and rheological characterization of vocal fold scarring was presented by Thibeault et al. ${ }^{21}$ in animal model study of vocal fold scarring and its treatment. The clinician who treated laryngeal injury should comprehend the basic science of wound healing process. ${ }^{22}$

In Indonesia no published data of post intubation laryngeal complication is available yet. In the meantime at Dr. Mohammad Hoesin Hospital, Palembang during the year 2017-2018, there were 4 cases of subglottic stenosis post prolonged intubation. 
In this research, 59 post intubation laryngeal injury subjects were studied. The highest frequency of laryngeal injury based on CALI categorization was severe degree laryngeal injury in 25 subjects $(42.4 \%)$. The risk factors associated with the incidence of laryngeal injury after intubation were age, duration of intubation, and kinking type of ETT.

There was a significant relationship between severe post intubation laryngeal injury and duration of intubation.

\section{REFERENCE}

1. Cho CK, Kim JJ, Sung TY, Jung SM, Kang PS. Endotracheal intubation-related vocal cord ulcer following general anesthesia. Korean J Anesthesiol. 2013; 65(6 Suppl): S147-8.

2. House JC, Noordzij JP, Murgia B, Langmore $S$. Laryngeal injury from prolonged intubation: A prospective analysis of contributing factors. Laryngoscope. 2011; 121(3): 596-600.

3. Cordeiro ALPC, Silva R, Prado CBC, Oliveira KF, Barbosa MH. Laryngotracheal mucosa injury and associated factors after endotracheal extubation: a pilot study. Acta Paul Enferm. 2017; 30(3): 316-22.

4. Benjamin B. Prolonged intubation injuries of the larynx: Endoscopic diagnosis, classification, and treatment. Ann Otol Rhinol Laryngol. 2018; 127(8): 492-507.

5. Lundy DS, Casiano RR, Shatz D, Reisberg M, Xue JW: Laryngeal injuries after shortversus long-term intubation. J Voice. 1998; 12 (3): $360-5$.

6. Brodsky MB, Levy MJ, Jedlanek E, Pandian V, Blackford B, Price C, et al. Laryngeal injury and upper airway symptoms after oral endotracheal intubation with mechanical ventilation during critical care: a systematic review. Crit Care Med. 2018; 46(12): 2010-7.

7. Schweiger C, Manica D, Kuhl G, Sekine L, Marostica PJC. Post-intubation acute laryngeal injury in infants and children: a new classification system. Int J Pediatr Otorhinolaryngol. 2016; 86: 177-82.

8. Lopez PCP, Berkow LC, Hillel AT, Akst LM. Complications of airway management. Respir Care. 2014; 59(6): 1006 -19.

9. Olszwesky A. Laryngeal injury in the intubated ICU patients. 2008. Thesis. Ohio State University, USA.

10. Kikura M, Suzuki K, Itagaki T, Takada T, Sato S. Age and comorbidity as risk factors for vocal cord paralysis associated with tracheal intubation. Br J Anaest. 2008; 98(4): 524-30.

11. Hughes AL, Karter N, Swanson DS. Laryngeal infection. In Infectious diseases in pediatric otolaryngology. Valdez T, Vallejo J (eds). 2016. Switzerland: Springer International Publishing, 2016. p. 151-61.

12. Mota L, Cavalho GB, Brito VA. Laryngeal complications by orotracheal intubation: literature review. Int Arch Otorhinolaryngol. 2012; 16(2): 236-45.

13. Shah MD, Nguyen LHP, Campisi P, James A, Taylor GP, Forte V. Piloting a novel porcine model for endolaryngeal injury following prolonged intubation. Int J Pediatr Otorhinolaryngol. 2007; 71(9): 1399-406.

14. Bishop MJ, Hibbard AJ, Fink BR, Vogel AM, Weymuller EA. Laryngeal injury in a dog model of prolonged endotracheal intubation. Anesthesiology. 1985; 62: 770-3.

15. Rangachari V, Sundararajan I, Sumathi V, Krishna KK. Laryngeal sequelae following prolonged intubation: a prospective study. Indian J Crit Care Med. 2006; 10(3):171-5.

16. Colice GL, Stukel TA, Dain B. Laryngeal complications of prolonged intubation. Chest. 1989; 96(4): 877-84

17. Santos PM, Afrassiabi A, Weymuller EA. Risk factors associated with prolonged intubation and laryngeal injury. Otolaryngol Head Neck Surg. 1994; 111: 453-9

18. Liu J, Zhang X, Gong W, Li S, Wang F, $\mathrm{Fu} \mathrm{S}$, et al. Correlation between controlled endotracheal tube cuff pressure and post procedural complications: a multicenter study. Anesth Analg. 2010; 111(5): 1133-7.

19. Li NYK, Vodovots Y, Hebda PA, Abbott KV. Biosimulation of inflammation and healing in surgically injured vocal folds. Ann Otol Rhinol Laryngol. 2010; 119(6): 412-23. 
20. Kahveci SF, Erisen L, Ozcan B, Kutlay O, Tezel I. Endoscopic diagnosis of laryngeal injury following endotracheal intubation. Minim Invasive Ther Allied Technol. 1999; 8(1): 55-8.

21. Thibeault SL, Gray SD, Bless DM, Chan RW, Ford CN. Histologic and rheological characterization of vocal fold scarring. J Voice. 2002; 16: $96-104$.

22. Branski RC, Verdolini K, Sandulache V, Rosen CA, Hebda P. Vocal fold wound healing: a review for clinicians. J Voice. 2006; 20(3): 432-42. 